\title{
Pengembangan manajemen kurikulum dan pembelajaran di pondok pesantren
}

\section{Darul Ilham *, Suyatno Suyatno}

Pascasarjana, Universitas Ahmad Dahlan.

J1. Kapas No.9, Semaki, Umbulharjo, Yogyakarta, Daerah Istimewa Yogyakarta 55166, Indonesia.

* Corresponding Author. E-mail: darul.ilham19@gmail.com

\section{ARTICLE INFO \\ Article History \\ Received: \\ 30 June 2020; \\ Revised: \\ 31 August 2020; \\ Accepted: \\ 2 September 2020 \\ Available online: \\ 25 September 2020}

\section{Keywords}

Manajemen kurikulum;

Manajemen

pembelajaran;

Muhammadiyah

Boarding School

(MBS);

Pondok pesantren;

Boarding school;

Curriculum

management;

Learning management;

\begin{abstract}
Penelitian ini bertujun untuk mendeskripsikan pengembangan manajemen kurikulum dan pembelajaran di Pondok Pesantren Muhammadiyah Boarding School (MBS) Prambanan Yogyakarta. Penelitian ini termasuk jenis penelitian kualitatif dengan pendekatan studi kasus. Data dikumpulkan melalui teknik wawancara, observasi, dan dokumentasi dari bagian hubungan masyarat (humas) di MBS. Data yang terkumpul dianalisis dengan menggunakan teknik analis induktif interaktif yang meliputi: reduksi data, display data, dan penarikan kesimpulan. Hasil penelitian menunjukkan bahwa: 1.) Prinsip pengembangan kurikulum terdiri dari empat: prinsip signifikasi sosial, prinsip pertumbuhan, prinsip perbedaan individu, dan prinsip integrasi; 2) Pengembangan kurikulum dan pembelajaran di MBS meliputi dua aspek penting, yaitu: integrasi kurikulum pendidikan nasional dan pondok pesantren, serta menjadikan MBS sebagai pusat pembinaan akhlak siswa. Integrasi kurikulum pendidikan nasional dan pondok pesantren dilakukan dengan cara MBS Prambanan menerima sepenuhnya kurikulum yang berlaku secara nasional berupa Kurikulum 2013 sebagai bagian dari mewujudkan cita-cita pendidikan nasional namun dengan menambah kurikulum pesantren khas MBS. Sedangkan MBS sebagai pusat pembinaan akhlak merupakan konsekuensi logis sekaligus perwujudan dari cita-cita lembaga yang ingin membekali para siswanya penguasaan sains dan teknologi sekaligus memiliki bekal ilmu-ilmu keagamaan. Pengembangan manajemen kurikulum dan pembelajaran di pondok pesantren diintergrasikan demi kemajuan di semua lembaga pendidikan.
\end{abstract}

This study aims to describe the development of curriculum management and learning in the Muhammadiyah Boarding School of Prambanan Yogyakarta. This research is qualitative research with a case study approach. Data collected through interviews, observation, and documentation techniques supported by the public relations section in MBS. The data collected was analyzed using interactive inductive analyst techniques which included; data reduction, data display, and conclusion drawing. The results show that: 1.) the principles of curriculum development consist of the following four: the principle of social significance, the principle of growth, the principle of individual differences, and the principle of integration; 2.) Curriculum development and learning in MBS Prambanan cover two important aspects, namely: first, integration of the national education curriculum and Islamic boarding school, and second; making Muhammadiyah Boarding School is the center of student morals development. Integration of the national education curriculum and Islamic boarding school is carried out by way of MBS fully accepting the nationally applicable curriculum in the form of the 2013 Curriculum as part of realizing the ideals of national education but by adding to the Islamic boarding school curriculum typical of MBS. Whereas Muhammadiyah Boarding School as a center for morality training is a logical consequence as well as a manifestation of the ideals of the institution that wants to equip its students to master science and technology while at the same time possessing religious knowledge. The development of curriculum management and learning in Islamic boarding schools is integrated for the sake of progress in all educational institutions.

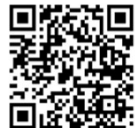

This is an open access article under the CC-BY-SA license.

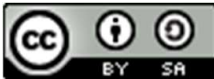

How to cite:

Ilham, D., \& Suyatno, S. (2020). Pengembangan manajemen kurikulum dan pembelajaran di pondok pesantren.

Jurnal Akuntabilitas Manajemen Pendidikan, 8(2), 186-195. doi: https://doi.org/10.21831/jamp.v8i1.32867 


\section{PENDAHULUAN}

Perkembangan teknologi informasi menuntut lembaga pendidikan untuk bergerak cepat agar mampu beradaptasi dengan dinamikan perubahan yang sangat cepat. Para pengelola dan praktisi lembaga pendidikan harus mampu melakukan berbagai terobosan dalam mengembangkan manajemen kurikulum dan pembelajaran agar mampu mengembangkan bakat dan minat siswa, sehingga lulusan lembaga pendidikan yang dikelola memiliki kompetensi yang dibutuhkan untuk hidup di zamannya. Dalam manajemen pembelajaran, penekanan ditempatkan pada pengaturan konten subjek dan kegiatan pembelajaran yang sesuai dengan kebutuhan dan bakat peserta didik sementara pada saat yang sama perbedaan individu juga diperhitungkan. Skema pendidikan seperti itu memberikan pelatihan untuk keterampilan berpikir dan manajemen, dan keterampilan untuk mengatasi situasi yang berubah, serta untuk memberikan peserta didik kesempatan untuk belajar dari situasi otentik. Pemanfaatan teknologi informasi sebagai alat untuk mencari pengetahuan juga telah ditekankan (Pamphilon, 2000).

Pendidik menjadi tolak ukur pertama dalam menjalankan kurikulum di sekolah secara efektif dalam proses pembelajaran. Cole dan Knowles (1993) menjelaskan bahwa guru yang efektif adalah mereka yang dapat secara spontan dan intuitif melakukan dan menilai kurikulum secara benar dan tepat. Schin (1983) menjelaskan bahwa tindakan guru harus menunjukkan epistimologi, pengalaman, dan refleksi yang berkelanjutan dari proses mengajar. Demikian juga, pengembangan kurikulum dapat menjadi proses spontan dan intuitif yang menggabungkan refleksi pengembang kurikulum. Kurikulum dapat dikembangkan dengan berbagai model. Morris dan Adamson (2010) berpendapat bahwa tidak ada model yang sempurna karena kekuatan satu model sering memiliki kelemahan dan sebaliknya. Dengan demikian, ia menyarankan bahwa pengembang kurikulum harus merefleksikan pengalamannya sendiri.

Konteks masyarakat dan sosial politik di mana sekolah itu berdiri juga perlu menjadi pertimbangan dalm mengembangkan kurikulum. Pentingnya pengembangan kurikulum dan pembelajaran dalam meningkatkan mutu sekolah, serta mutu pembelajaran di dalam kelas, sekolah harus dapat mengantisipasi perubahan yang ada di dalam kurikulum tersebut. Kurikulum di dunia pendidikan akan selalu mengalami perubahan atau pembaharuan untuk menjadi lebih baik. Hal ini dilakukan karena kurikulum memiliki fungsi yang sangat penting dan krusial. Kurikulum merupakan sejumlah pengalaman yang harus dilalui oleh siswa dalam menyelesaikan satu jenjang pendidikan tertentu. Selain sejumlah mata pelajaran yang harus dipelajari oleh siswa, kurikulum juga memuat sejumlah program dan kegiatan baik yang terencana mapun tidak terencana yang diperoleh oleh siswa selama menyelesaikan jenjang pendidikan tertentu dalam rangka untuk meningkatkan kompetensinya. Selama proses pembelajaran, siswa dituntut agar mencapai berbagai kompetensi yang telah ditargetkan oleh sekolah dalam kurikulumnya. Untuk mencapai kompetensi tersebut, peran guru sebagai ujung tombak implementasi kurikulum sangat vital. Kurikulum tidak dibatasi hanya sebagai aktivitas yang ada di dalam kelas, namun juga seluruh aktivitas yang ada di luar kelas yang dapat meningkatkan pengalaman dan kompetensi siswa.

Pengembangan manajemen kurikulum dan pembelajaran harus bersifat komperehensif dan sistematik. Oleh karena itu, demi ketercapaian kurikulum manajemen sekolah harus dapat mengembangkan dengan konteks manjemen berbasis sekolah. Dalam pelaksanaannya, masing-masing sekolah memiliki kewenangan dan desentralisasi dalam menjalankan kurikulum. Bentuk desentralisasi itu dapat berupa pengembagan kultur sekolah dan muatan lokal yang sesuai dengan karakteristik dan kebutuhan masing-masing sekolah (Hamalik \& Oemar, 2011). Manajemen pembelajaran bagian dari komponen dalam manajemen kurikulum yang dilakukan oleh guru di kelas agar proses belajar mengajar di kelas berjalan efektif dan dapat mengantarkan siswa mencapai kompetensi yang telah ditetapkan. Manajemen pembelajaran dilakukan sebagai bagian dari aktivitas professional dalam menggunakan, serta memilihara kurikulum yang dilaksanakan. Dalam menjalankan fungsi manajemen pembelajaran, guru dituntut dapat memanfaatkan semua sumber daya pendukung yang dimiliki oleh sekolah (Hamalik \& Oemar, 2011).

Penelitian ini berusaha mendeskripsikan pengembangan manajemen kurikulum dan pembelajaran di pondok pesantren Muhammadiyah Boarding School (MBS), Prambanan, Yogyakarta. Pengembagan Manajemen Kurikulum dan pembelajaran di MBS menarik diteliti, 
karena lembaga ini disamping menerapkan kurikulum yang berlaku secara nasional, juga memiliki kurikulum sekolah yang memiliki karakteristik yang berbeda dengan sekolah-sekolah secara umum. Perpaduan dua kurikulum tersebut dilakukan dengan tujuan untuk membentuk para siswa menjadi pribadi muslim yang menguasasi sains dan teknologi dan ilmu-ilmu keagamaan secara berimbang. Secara detail, penelitian ini menjawab dua pertanyaan sebagai berikut: 1.) Bagaimanakah prinsip pengembangan manajemen kurikulum dan pembelajaran?; dan 2.) Bagaimanakah implementasi pengembangan kurikulum dan pembelajaran di Pondok Pesantren MBS, Prambanan, Yogyakarta? Temuan penelitian ini diharapkan dapat menyediakan wawasan ilmiah kepada para praktisi pendidikan tentang pengembangan manajemen kurikulum dan pembelajaran di sekolah.

\section{METODE}

Penelitian ini merupakan jenis penelitian kualitatif dengan pendekatan studi kasus (Creswell \& Poth, 2013). Penelitian kualitatif merupakan penelitian yang berusaha mendeskripsikan sebuah peristiwa yang terjadi secara alami. Sedangkan pendekatan studi kasus cocok digunakan untuk penelitian yang melibatkan peristiwa kontemporer yang dipelajari dalam setting yang alami dan peneliti tidak melakukan intervensi terhadap perilaku subjek yang diteliti (Gomm, Hammersley, \& Foster, 2000; Hitchcock \& Hughes, 1995; Noor, 2008). Studi kasus memungkinkan data penelitian dikumpulkan dengan berbagai metode dan sumber (Green, Camilli, \& Elmore, 2006) menggabungkan deskripsi dengan analisis peristiwa dan data (Denzin \& Lincoln, 2011; Reason \& Bradbury, 2001; Vandenberghe \& Kelchtermans, 2002). Dalam penelitian ini menggunakan dua sumber data, yaitu sumber data primer dan sumber data sekunder. Sumber data primer adalah data-data yang diperoleh dari wawancara kepada kepala sekolah, guru, dan siswa. Sedangkan sumber data sekunder berupa data dokumentasi dan arsip-arsip penting. Contoh lainnya yaitu, buku-buku yang relevan dengan judul penelitian.

Teknik pengumpulan data dilakukan melalui wawancara dan dokumentasi. Peneliti melakukan wawancara kepada kepala sekolah, guru, dan siswa. Dalam melakukan wawancara peneliti dipandu oleh pedoman wawancara yang telah disiapkan sebelumnya. Sedangkan dokumentasi dilakukan dengan cara mengumpulkan data-data yang relevan dengan topik penelitian, seperti dokumen kurikulum. Data yang terkumpul dianalisis dengan menggunakan analisis data induktif kualitatif model Miles dan Huberman (1994) yang meliputi reduksi data, penyajian data, dan penarikan kesimpulan.

\section{HASIL DAN PEMBAHASAN}

Hasil

Data dalam penelitian ini diuraikan berdasarkan urutan dalam menjawab rumusan masalah yang diajukan. Ada dua tema pokok dalam penyajian data penelitian ini yaitu; 1) Konsep Dasar Prinsip Pengembangan Kurikulum dan Pembelajaran, 2) Pengembangan manajemen dan pembelajaran di Muhammadiyah Boarding School (MBS).

\section{Prinsip-Prinsip Pengembangan Kurikulum dan Pembelajaran}

Dalam mengembangkan kurikulum, diperlukan prinsip-prinsip tertentu yang harus diikuti. Prinsip-prinsip ini akan membantu penyelenggara lembaga pendidikan mencapai tujuan yang telah ditetapkan. Prinsip-prinsip tersebut perlu mempertimbangkan berbagai kebijakan pemerintah dalam bidang pendidikan, misalnya; undang-undang sistem pendidikan nasional, kurikulum nasional yang dirancanang oleh Badan Standar Nasional Pendidikan (BSNP), manajemen berbasis sekolah, dan kebijakan-kebijakan lain yang relevan dengan pengembangan kurikukul dan pembelajaran.

Kurikulum merupakan sejumlah rencana dan program yang dibuat oleh satuan pendidikan tentang sejumlah pengalaman yang akan dilalui oleh siswa di sekolah. Dalam mengembangkan kurikulum, perlu memperhatikan asas-asas pengembangan kurikulum baik dari segi filsafat, nilai, pengetahuan tentang bagaimana pendidikan yang ideal dijalankan. Dalam pelaksanaannya, kurikulum dirancang dengan melibatkan banyak pihak dari ahli pendidikan, ahli kurikulum, pendidik, ilmu- 
wan, pemangku kebijakan, stakeholder, serta unsur-unsur masyarakat yang lain. Rancangan ini dibuat agar dapat menjadi pedoman bagi para praktisi dan penyelenggara pendidikan dalam mendampingi para siswa mencapai kompetensi dan pengalaman yang diharapkan (Syaodih, 2010). Prinsip artinya asas, dasar, keyakinan, dan pendirian. Dengan demikian, kata prinsip memiliki makna bahwa suatu hal yang mendasar, penting, sehingga harus menjadi perhatian berbagai pihak. Prinsip memiliki sifat mengatur dan mengarahkan. Prinsip memiliki fungsi penting terhadap keberadaan sesuatu. Prinsip juga mencerminkan hakikat yang dikandung oleh sesuatu baik dalam dimensi proses maupun hasil, dan bersifat memberikan rambu-rambu atau aturan main yang harus diikuti untuk mencapai tujuan secara benar (Tim Pengembang MKDP, 2011).

Prinsip pengembangan kurikulum menjadi dasar bagi para pengembang kurikulum dalam menjalankan tugasnya. Prinsip-prinsip tersebut menjelaskan bahwa dalam mengembangkan kurikulum perlu menggunakan pedoman dalam melakukan perencanaan kurikulum, pelaksanaan kurikulum, dan evaluasi kurikulum. Prinsip-prinsip tersebut sekaligus mencerminkan hakikat dan ciri kurikulum itu sendiri. Pengembangan kurikulum meliputi proses identifikasi, analisis, sintesis, evaluasi, pengambilan keputusan, dan inovasi berbagai komponen kurikulum. Prinsip-prinsip pengembangan kurikulum tersebut jika ditaati oleh pengembang kurikulum akan menjadikan proses pengembangan kurikulum berjalan dengan baik dan hasilnya juga efektif. Produk dari aktivitas pengembangan kurikulum akan relevan dengan kebutuhan dan harapan masyarakat. Dengan mengikuti prinsip-prinsip tertentu, produk pengembangan kurikulum juga dapat dipertanggungjawabkan kepada semua pihak, baik pemangku kebijakan, siswa, pendidik, dan masyarakat.

Selain prinsip, pengembangan kurikulum yang efektif juga perlu memperhatikan fungsifungsi tertentu, yang meliputi; 1.) Pemanfaatan sumber daya kurikulum melalui pengeloaan yang terencana dan efektif; 2.) Keadilan dan kesempatan yang sama kepada para siswa agar tujuan pembelajaran dapat tercapai dengan optimal; 3.) Keluasan dan kedalaman kurikulum harus disesuaikan dengan kebutuhan peserta didik dan lingkungan sekitar; 4.) Meningkatkan efektivitas kinerja guru maupun siswa dalam mencapai tujuan pembelajaran; dan 5.) Dapat meningkatkan partisipasi masyarakat dengan cara sumber belajar disesuaikan dengan ciri khas dan kebutuhan pembangunan di daerah sekitar.

Kurikulum pada umumnya mengakui pentingnya untuk pengembangan program pendidikan terpadu seperti halnya mereka dengan kurikulum kepentingan pribadi lama yang sangat terkotak. Dan semakin banyak spesialis menjadi khawatir bahwa kompetensi khusus mereka bersatu secara integral untuk membuat kesempatan pendidikan bagi anak-anak yang lebih besar daripada sekadar penambahan satu bidang ke bidang lainnya. Pentingnya dalam mempertimbangkan prinsip-prinsip panduan dalam mengembangkan seluruh kurikulum memberikan kontribusi yang sangat siginifikan di dalam dunia pendidikan. Dalam mengembagkan kuirikulum terdapat empat prinsip yang sangat penting di dalamnya yang pertama yaitu prinsip signifikasi sosial, prinsip pertumbuhan, prinsip perbedaan individual, dan prinsip integrasi.

\section{Prinsip Signifikansi Sosial}

Harus diakui bahwa sistem sekolah didirikan dan dikelola oleh masyarakat untuk membantu mencapai tujuan sosial. Setiap masyarakat modern mendukung sistem sekolah. Ini dilakukan bukan karena tradisi atau altruisme, tetapi karena pendidikan yang terorganisir dipandang sebagai sarana utama untuk mencapai nilai-nilai yang diperjuangkan kelompok sosial. Pentingnya basis sosial dari program pendidikan ini terlihat ketika kita mengenali sejumlah besar seleksi yang harus dilakukan dalam mengatur kurikulum sekolah. Budaya kita sangat kompleks sehingga siapa pun dapat memperoleh pengalaman hanya dengan sebagian kecil saja. Akibatnya salah satu tugas paling sulit dari pekerja kurikulum adalah untuk menentukan aspek budaya apa yang harus dimasukkan dalam kurikulum. Masalahnya semakin rumit dengan perjuangan berbagai mata pelajaran dan bidang untuk mendapatkan tempat dalam kurikulum. Tinjauan atas laporan buku tahunan, misalnya, menunjukkan bahwa hampir setiap kelompok mata pelajaran menekan lebih banyak waktu dalam kurikulum. Prinsip signifikansi sosial memberikan panduan penting bagi pekerja kurikulum dalam menyelesaikan masalah. 


\section{Prinsip Pertumbuhan}

Kedua yaitu prinsip pertumbuhan. Ada banyak hal dalam proses ini yang menjadi perhatian utama bagi siapa saja yang melakukan untuk merencanakan kurikulum. Oleh karena peserta didik berawal dari anak-anak yang akan tumbuh dewasa, apa yang pantas pada suatu waktu dalam kegiatan dan bimbingan mungkin tidak pantas di waktu lain, dan apa yang merupakan harapan yang masuk akal pada suatu waktu adalah harapan yang sepenuhnya tidak masuk akal di waktu lain, serta apa yang mewakili, perilaku yang dapat diterima pada suatu waktu adalah perilaku yang tidak dapat diterima di waktu lain. Oleh karena itu, program sekolah harus dikembangkan dengan pengakuan penuh terhadap tingkat pertumbuhan dari peserta didik. Kegiatan, bahan, bimbingan, harapan semua aspek kurikulum harus memperhitungkan status pertumbuhan anak yang diajar.

\section{Prinsip Perbedaan Individu}

Ketiga yaitu perbedaan individu. Dalam mengembangkan kurikulum untuk memenuhi kebutuhan siswa pada berbagai tingkat kemampuan, siswa cenderung merasa bahwa tidak banyak yang bisa dikatakan. Faktanya adalah, implikasi paling penting dari perbedaan individu tidak dirasakan dalam banyak rencana kurikulum. Ada tiga fakta yang tak terhindarkan yang harus dihadapi pekerja pendidikan tentang perbedaan individu. Ini bukan fakta yang hanya bisa ditoleransi dalam pekerjaan sekolah, melainkan mereka harus dijadikan pertimbangan dasar untuk memasuki semua fase perencanaan dan pengembangan program kurikulum. Yang pertama adalah bahwa keberadaan perbedaan individu adalah kondisi alam yang normal yang pasti hadir dalam semua karakteristik dan kemampuan. Perbedaan individu tidak dapat dihilangkan meskipun diinginkan untuk melakukannya. Apakah itu berlari, melompat, membaca, berbicara, mengetik, melukis gambar, tinggi, berat, atau kecerdasan, jangkauan pencapaian yang luas di antara individu adalah normal dan tak terhindarkan. Tidak hanya individu sangat berbeda satu sama lain dalam hal kemampuan dan karakteristik tetapi seseorang yang diberikan akan sangat bervariasi dalam kemampuan dan karakteristik yang berbeda. Memang benar bahwa secara umum seseorang yang cenderung lebih unggul pada satu titik, akan cenderung lebih unggul dalam hal lain.

Yang kedua yang sering diabaikan adalah bahwa perbedaan bukanlah kejahatan yang tak terbantahkan yang dianggap oleh para pekerja sekolah. Sebagian besar kekayaan hidup dan banyak pencapaian penting muncul dari perbedaan dalam kapasitas, kemampuan, dan pandangan mereka. Di mana ada pemimpin harus ada pengikut, di mana ada produsen seni harus ada konsumen seni. Pencapaian fenomenal dalam garis apa pun adalah fenomenal hanya jika dibandingkan dengan pencapaian orang lain yang tidak melakukannya dengan baik. Yang ketiga, pendidikan, jika memadai, cenderung meningkat daripada mengurangi sebagian besar perbedaan. Perbandingan berbagai budaya menunjukkan bahwa masyarakat dimana terdapat tingkat peradaban yang lebih tinggi menunjukkan rentang perbedaan yang jauh lebih luas antara individu daripada masyarakat dengan tingkat peradaban yang lebih rendah.

\section{Prinsip Integtasi}

Prinsip yang terakhir yaitu integrasi. Jelas bahwa seseorang berkembang secara keseluruhan, bukan dalam segmen. Telah terbukti bahwa tidak mungkin untuk memberikan pengalaman yang hanya memengaruhi sebagian individu. Setiap aktivitas dimana orang terlibat, setiap pengalaman yang dimilikinya, melibatkannya sebagai organisme total. Perubahan yang terjadi sebagai hasil dari pengalaman sama-sama meresap, mewakili dalam arti yang sangat nyata suatu remake lengkap dari organisme. Ketika seseorang berpikir, seluruh keberadaannya, aspek biologis, dan emosional serta intelektual, dilibatkan dan sedang diubah. Tidak mungkin untuk memisahkan elemen-elemen ini dalam situasi belajar atau untuk menghilangkan pengaruh masing-masing pada semua tanggapan yang dilakukan seseorang.

\section{Pengembangan Manajemen Kurikulum dan Pembelajaran di MBS}

Pengembangan kurikulum dan pembelajaran merupakan sebuah keniscayaan bagi lembaga pendidikan agar proses pendidikan yang dilaksananakan sesuai dengan kebutuhan siswa dan tuntutan zaman. Majid (2005) menjelaskan bahwa pengembangan merupakan proses dalam mendesain sebuah pembelajaran. Agar pengembangan tersebut efektif, maka harus memperhatikan prinsip logis 
dan sistematis dalam proses pelaksanaannya dengan berdasarkan pada potensi dan kompetensi peserta didik (Majid, 2005).

Pengembangan pembelajaran merupakan usaha yang dilakukan terutama oleh guru di kelas dalam meningkatkan mutu pembelajaran, baik terkait dengan materi pembelajaran, media, dan metode yang digunakan, bahkan juga evaluasi pembelajaran yang dilakukan. Pengembangan materi pembelajaran berarti bahwa guru mengembangkan materi yang diajarkan agar sesuai dengan perkembangan ilmu pengetahuan terkini dan konteks kehidupan siswa. Pengembangan media dan metode pembelajaran berarti bahwa baik media dan metode yang digunakan oleh guru dalam mengajar harus memperhatikan perkembangan sains dan teknologi, kebutuhan siswa, dan karakteristik materi yang diajarkan. Pengembangan evaluasi pembelajaran berkenaan dengan teknik dan instrumen yang digunakan oleh guru dalam melakukan penilaian baik proses maupun hasil belajar dan evaluasi harus bersifat otentik (Hamid, 2013).

Pembahasan

\section{Integrasi Kurikulum Nasional dan Pesantren}

Pengembangan kurikulum yang dilakukan oleh pondok pesantren modern Muhammadiyah Boarding School (MBS) yaitu menerapkan perpaduan antara kurikulum pendidikan nasional yang mengacu pada kurikulum 2013, serta kurikulum pesantren yang berangkat dari pendidikan pesantren modern. Program pesantren yang dilaksanakan oleh pondok pesantren MBS ini ialah tahfidz AlQur'an dan Al-Hadits Al-Lughoh Al-Yaumiyah, olah raga dan bela diri, jurnalistik, kemasyarakatan, dan keorganisasian. Sebagai program penunjang, MBS juga mengadakan program remedial teaching bagi peserta didik yang mengalami kesulitan dalam belajar. Bagi peserta didik kelas 3 dan 6, disediakan bimbingan belajar intensif untuk ujian nasional, serta bimbingan belajar intensif ujian pondok. Sementara itu, program unggulan pesantren ialah tahfidz Al-Qur'an, penyaluran minat dan bakat, serta program bahasa, yaitu bahasa Arab dan bahasa Inggris.

Kurikulum yang diterapkan di MBS sesuai dengan konsep yang ditawarkan Kuntowijoyo (2007) dalam kaitannya dengan pendidikan Islam berbasis profetik. Konsep yang dimaksud adalah metodologi integralisasi dan objektifikasi (Kuntowijoyo, 2007). Perpaduan kurikulum sebagaimana yang telah disebutkan merupakan perwujudan dari integralisasi. Dengan adanya integrasi atau perpaduan antara Islam dan ilmu maka diharapakan juga ada penyatuan antara wahyu Tuhan dan pikiran manusia. Hal inilah yang lebih banyak membedakan pendidikan profetik dan pendidikan Islam yang selama ini dipakai, pendidikan Islam yang selama ini digunakan oleh lembaga pendidikan Islam lebih kepada Islamisasi atau doktrinasi.

Sebagai bagian dari konsep pendidikan profetik dan pengimplementasian dari kurikulum yang digunakan, MBS mengadakan tahfidz Al Qur'an dan Al-Hadits Al-Lughoh Al-Yaumiyah, olah raga dan bela diri, jurnalistik, keorganisasian dan kemasyarakatan, dan keorganisasian. Program tersebut merupakan konsep pendidikan profetik. Program ini telah sesuai dengan dengan tujuan pendidikan profetik yang tidak lepas dari nilai nilai Al-Qur'an dan Sunnah, yakni prinsip integrasi, prinsip keseimbangan, persamaan dan pembebasan, kontinuitas dan berkelanjutan serta prinsip kesehatan dan keutamaan (Nazir, 2011). Integrasi kurikulum pendidikan pesantren dan pendidikan nasional di MBS ialah upaya untuk mengkolaborasikan konsep pendidikan Islam berbasis Al-Quran dan Sunnah dengan pendidikan modern. Dengan demikian, dengan pendidikan integrative ini siswa mampu terbuka dengan ilmu-ilmu alam, ilmu sosial, ilmu humaniora, serta ilmu pengetahuan dan teknologi yang berbasis budaya.

Buah harapannya adalah tercipta siswa dan manusia yang tidak bersikap hedonis, materialis, dan sekuler, hal inilah sebab agama dihadirkan senafas dengan keilmuan. Komponen kurikulum yang meliputi tujuan, materi, strategi pembelajaran, dan evaluasi diarahkan kepada penanaman nilai Islam berbasis cita-cita etik dan profetik. Rosyadi (2009) menjelaskan bahwa pada strata sekolah menengah kurikulum diorientasikan pada pemehaman, pengembangan dan penerapan keya-kinan keislaman, kecintaan kepada Nabi, serta pemahaman mengenai hubungan antara ilmu dan amal, antara ilmu dan pembangunan nasional, sehingga tercipta kepekaan rasa, ketajaman intelektual serta mampu berkomunikasi. 
Bloom (1956) menjelaskan bahwa aspek yang harus dibangun dalam diri peserta didik ialah aspek kognitif, afektif, dan psikomotor. Sejalan dengan itu, MBS membangun tujuan dalam rangka mencetak kader bangsa yang kuat dalam iman, berilmu, serta berakhlak mulia untuk kemudian diharapkan turut terlibat dalam membangun bangsa sesuai dengan perkembangan zaman. Tujuan pembelajaran sebagai perwujudan dari kurikulim ini diarahkan pada integrasi kurikulum umum, yakni kurikulum pendidikan nasional dan kurikulum pesantren modern. Sesuai dengan jenjang pendidikan strata menengah, maka orientasi materi pendidikan Islam diarahkan pada materi alQur'an, Hadits, sirah dan sejarah Islam, fiqh, bahasa Arab, matematika, ilmu bumi dan sejarah kultur peradaban (Rosyadi, 2009).

Subtansi materi inilah yang diberikan dan internalisasikan dalam diri siswa di pondok pesantren MBS Yogyakarta. Di MBS sendiri, materi yang diberikan ialah faroid, kemuhammadiyahan, nahwu, mahfudzot, insya, tahsin, Al-Qur'an, mutholaah, fiqh, aqidah, hadits, ulumul Qur'an, tamrin lughoh, mustolah hadis, tarikh, balagoh, fiqhiyah, turuq tadris, shorof, dan lain sebagainya. Prinsip yang perlu diperhatikan dalam evaluasi pendidikan, khususnya dalam pendidikan Islam berbasis profetik ialah prinsip kontinyuitas, prinsip menyeluruh dan prinsip obyektivitas. Adapun mengenai evaluasi pendidikan berbasis profetik, tugas monitoring peserta didik tidak hanya bertumpu pada guru saja, namun semua tenaga kependidikan serta orangtua siswa turut terlibat dalam evaluasi. Tujuan pendidikan hakikatnya merupakan upaya untuk mengarahakan serta membimbing kegiatan guru dan murid dalam proses belajar mengajar demi tercapainya tujuan yang disepakati. Tujuan pendidikan Islam sendiri diarahakn untuk membentuk kepirbadian muslim yang paripurna (insan kamil), sehingga mampu menjadi rahmat bagi seluruh alam.

Tujuan pendidikan profetik tidak bisa terlepas dari prinsip Islam yang berasal dari spirit AlQur'an dan Sunnah. Pertama, prinsip integrasi yang memandang bahwa terdapat keterpaduan dan kesatuan antara dunia dan akhirat. Kedua, prinsip keseimbangan yakni keseimbanan antara rohaniah dan jasmaniah, ilmu murni dan terapan, teori, dan praktik, antara nilai yang menyangkut antara syariah, aqidah, dan akhlak. Ketiga ialah prinsip persamaan dan kebebasan, yakni manifestasi dari prinsip tauhid, bahwa semua orang sama sebagai makhluk dan berasal dari pencipta yang sama. Keempat, prinsip kontinuitas dan berkelanjutan. Konsep dan prinsip ini adalah manifestasi dari konsep pendidikan seumur hidup. Dalam Islam, kegiatan pendidikan adalah kewajiban yang tidak boleh berakhir. Kelima, prinsip kemaslahatan dan keumatan. Prinsip tauhid yang masuk dalam sistem moral memiliki energi yang banyak untuk membela hal-hal yang bersifat maslahah atau berguna bagi kehidupan.

Isi kurikulum merupakan salah satu komponen kurikulum yang berkenaan dengan sejumlah pengetahuan dan materi pelajaran yang tergambar dalam isi mata pelajaran. Prinsip yang digunakan dalam merancang materi ialah; 1.) Pengembangan pendekatan religius yang meliputi semua cabang ilmu pengetahuan; 2.) Isi pelajaran yang bersifat religius terlepas dari materi yang jumud dan tidak bermakna; dan 3.) Perencanaan yang mempertimbangkan prinsip kontinuitas atau kesinambungan, sekuensi dan integrasi. Pada paradigma pengembangan pendidikan profetik, dalam tingkat menengah, materi yang dapat dikembangkan terkait dengan keterampilan atau strategi membaca cepat serta kreativitas menulis. Media adalah sarana yang menjembatani dalam pengajaran. Media yang dipakai oleh pendidik akan mempermudah peserta peserta didik dalam menanggapi serta memahami sajian isi dari pendidik. Media ini diperlukan dalam upaya mengatasi hambatan psikologis, fisik, kultural dan lingkungan. Pada masa kenabian Muhammad saw, media dakwah atau pembelajaran yang dipakai masih sangat sederhana. Tentu hal tersebut sangat berbeda dengan zaman pada sekarang ini yang selalu mengalami perkembangan teknologi dan informasi yang semakin cepat dan canggih.

Dalam pendidikan nalar profetik, media harus mampu menjadi sarana dan alat pembantu bagi tercapainya tujuan pembelajaran. Meski demikian, guru juga harus lebih berhati-hati dalam menggunakan teknologi, sebab dikhawatirkan teknologi justru lebih mapan dari kekuatan guru dalam membentuk kepribadian murid di dalam kelas. Prinsip yang perlu diperhatikan dalam evaluasi pendidikan, khususnya dalam pendidikan Islam berbasis profetik ialah prinsip kontinyuitas atau berkesinambungan, prinsip menyeluruh, dan prinsip obyektivitas. Adapun mengenai evaluasi pendidikan berbasis profetik, tugas monitoring peserta didik tidak hanya bertumpu pada guru saja, namun semua tenaga kependidikan serta orangtua siswa turut terlibat dalam evaluasi. 
Sebagai upaya dalam membumikan nilai-nilai profetik dengan metode tauladan dan pembiasaan, peran pimpinan pondok adalah sebagai pihak yang terus memberikan kontrol atas jalannya pembelajaran yang memiliki nilai Islam sesuai dengan Al-Qur'an dan Sunnah. Struktur pimpinan MBS selalu mengadakan pengayaan, bukan hanya kepada siswa namun juga kepada para guru. Perbedaaan latar belakang pendidikan menjadikan para guru kerap tak sejalan dalam menjalankan perannya sebagai pendidik. Dalam konteks ini, pimpinan lembaga memberikan pembinaan dan pengayaan serta pengawasan pada proses pengajaran guru di sekolah.

\section{Muhammadiyah Boarding School Sebagai Pusat Pembinaan Akhlak}

Sebagai lembaga yang memiliki visi membangun peserta didik yang memiliki keunggulan moral dan intelektual, Muhammadiyah Boarding School merupakan pusat pembinaan akhlak sekaligus pengembangan ilmu-ilmu umum. Muhammadiyah Boarding School memiliki tanggung jawab untuk menyiapkan generasi yang memiliki kepribadian yang sesuai dengan nilai-nilai Islam yang bersumber dari ajaran Al-quran dan Hadits. Karakter tanggung jawab, jujur, amanah atau dapat dipercaya, dan berintegritas, merupakan contoh dari penanaman dan pembentukan karakter peserta didik di Muhammadiyah Boarding School sebagai pusat pembinaan akhlak.

\section{Ketaatan dalam Beribadah}

Ketaatan beribadah merupakan karakter utama bagi siswa MBS Prambanan. Para guru dan ustadz di MBS Prambanan selalu menekankan kepada para siswa bahwa ibadah merupakan kebutuhan bagi seorang muslim, sekaligus sebagai hamba Tuhan. Ibadah bukan dianggap sebagai beban. Perbedaan cara pandang terhadap ibadah ini akhirnya akan berdampak terhadap semangat para siswa dalam menjalankannya. Siswa yang memandang bahwa ibadah merupakan kebutuhan maka ia akan menjalankan ibadah tersebut dengan ringan dan mudah. Namun bagi siswa yang memandang ibadah sebagai sebuah beban dan belum menjadikannya sebuah kebutuhan, maka ia akan merasa berat dalam menjalankannya. Selain ibadah wajib, Muhammadiyah Boarding School juga membiasakan para siswa agar menjalankan ibadah yang bersifat sunnah. Beberapa contoh ibadah sunnah yang dilaksanakan para siswa adalah: puasa sunah senin kamis, puasa daud, sholat-sholat sunnah, tadarus AlQuran, dan amalan-amalan sunnah yang lain menjadi kebiasaan para santri di pondok MBS tersebut. Peserta didik menjalan dengan penuh kesadaran diri dan tanggung jawab tanpa mengganggu aktivitas-aktivitas lain yang diwajibkan oleh pondok pesantren.

Selain ketaatan dalam beribadah, MBS juga membentuk karakter siswa berupa semangat menutut ilmu, kejujuran, kedisiplinan, kepedulian terhadap lingkungan sekitar, dan membangun pergaulan yang baik dengan sesama. Manajemen modern yang diterapkan oleh MBS tidak menjadikan lembaga ini kehilangan ciri khas kepesantrenannya. Para santri dituntun untuk selalu menghormati para pembimbing, ustadz, dan seluruh pembina di asrama. Para santri juga dibentuk dan dibiasakan agar memiliki kepedulian sosial yang tinggi dengan melaksanakan berbagai program dan kegiatan seperti amal bakti santri dan bakti sosial pada masyarakat umum.

\section{SIMPULAN}

Ada dua kesimpulan dalam penelitian ini. Pertama, pengembangan kurikulum menganut empat prinsip, yaitu; prinsip signifikasi sosial, prinsip pertumbuhan, prinsip perbedaan individu, dan prinsip integrasi. Prinsip signifikansi sosial bermakna bahwa sekolah didirikan dan berdiri di tengahtengah masyarakat. Oleh karena itu, proses kurikulum dan pembelajaran di sekolah harus mampu membantu masyarakat dalam mencapai tujuan sosialnya. Prinsip pertumbuhan adalah prinsip yang memperhatikan fase-fase perkembanan peserta didik yang selalu tumbuh dan berkembang baik secara fisik maupun psikis. Pertumbuhan peserta didik meniscayakan kurikulum dan pembelajaran di sekolah perlu beradaptasi dengan situasi, kondisi, dan tuntutan di tempat dan waktu peserta didik hidup. Prinsip perbedaan individu meniscayakan pengembangan kurikulum dan pembelajaran di sekolah mengakomodasi perbedaan individual siswa. Mereka memiliki bakat, minat, karakteristik perkembangan yang berbeda satu sama lain. Prinsip yang terakhir, integrasi bermakna bahwa pengembangan kurikulum dan pembelajaran harus mampu membentuk para siswa tumbuh menjadi 
pribadi yang utuh, tidak mengalami split-personality. Pribadi yang memiliki kesimbangan jiwa dan raga, pengetahuan, sikap dan ketrampilan, aspek duniawi dan juga $u k r o w i$.

Kedua, implementasi pengembangan manajemen kurikulum dan pembelajaran di Muhammadiyah Boarding School meliputi dua hal, yaitu; integrasi kurikulum pendidikan nasional dan pondok pesantren, dan menjadikan Muhammadiyah Boarding School sebagai pusat pembinaan akhlak siswa. Integrasi kurikulum pendidikan nasional dan pondok pesantren dilakukan dengan cara menerima sepenuhnya kurikulum yang berlaku secara nasional berupa Kurikulum 2013 sebagai bagian dari mewujudkan cita-cita pendidikan nasional, namun dengan menambah kurikulum pesantren khas Muhammadiyah Boarding School itu sendiri. Sedangkan MBS sebagai pusaat pembinaan akhlak merupakan konsekuensi logis sekaligus perwujudan dari cita-cita lembaga yang ingin membekali para siswanya dalam penguasaan sains dan teknologi sekaligus memiliki bekal ilmu-ilmu keagamaan.

\section{DAFTAR PUSTAKA}

Bloom, B. S. (1956). Taxonomy of educational objectives, handbook the cognitive domain. New York: David McKay.

Cole, A. L., \& Knowles, J. G. (1993). Shattered images: Understanding expectations and realities of field experiences. Teaching and Teacher Education, 9(5-6), 457-471. doi: https://doi.org/10.1016/0742-051X(93)90030-K

Creswell, J. W., \& Poth, C. N. (2016). Qualitative inquiry and research design: Choosing among five approaches $\left(3^{\text {rd }}\right.$ ed.). Sage Publications.

Denzin, N. K., \& Lincoln, Y. S. (Eds.). (2011). The Sage handbook of qualitative research. Sage Publications.

Gomm, R., Hammersley M., \& Foster, P. (Eds.). (2000). Case study method: Key issues, key texts. Sage Publications.

Green, J. L., Camilli, G., \& Elmore, P. B. (2006). Handbook of complementary methods in education research. Mahwah, NJ: Lawrence Erlbaum.

Hamalik, H., \& Oemar, O. (2011). Kurikulum dan pembelajaran. Jakarta: Bumi Aksara.

Hamid, H. (2013). Pengembangan sistem pendidikan di Indonesia. Bandung : Pustaka Setia.

Hitchcock, G., \& Hughes, D. (1995). Research and the teacher. London: Routledge.

Kuntowijoyo, K. (2007). Budaya dan masyarakat. Yogyakarta: Tiara Wacana.

Majid, A. (2005). Perencanaan pembelajaran. Bandung: Remaja Rosdakarya.

Miles, M. B., \& Huberman, M. (1994). Qualitative data Analysis: An expended sourcebook. Sage Publications.

Morris, P., \& Adamson, B. (2010). Kurikulum, sekolah dan masyarakat di Hong Kong. Hong Kong University Press.

Nazir, M. (2011). Metode penelitian. Bogor: Penerbit Ghalia Indonesia.

Noor, K. B. M. (2008). Case study: A strategic research methodology. American Journal of Applied Sciences, 5(11), 1602-1604. doi: https://doi.org/10.3844/ajassp.2008.1602.1604

Pamphilon, B. (2000). Membalikkan ikan dari air: Peran pendidik dalam pengembangan keterampilan berpikir kritis. Bangkok: Universitas Chulalongkorn.

Tim Pengembang MKDP. (2011). Kurikulum dan pembelajaran. Jakarta: RajaGrafindo.

Reason, P., \& Bradbury, H. (Eds.) (2001). Handbook of action research: Participative inquiry and practice. Sage publications.

Rosyadi, K. (2009). Pendidikan profetik. Yogyakarta: Pustaka Pelajar.

Volume 8, No. 2, September 2020 
Schin, E. (1983). Organizational culture: A dynamic model. United State: Massachusetts Institute of Technology.

Syaodih, N. (2010). Pengembangan kurikulum. Bandung: PT Remaja Rosdaya.

Vandenberghe, R., \& Kelchtermans, G. (2002). Leraren die leren om professioneel te blijven leren: kanttekeningen over context. Pedagogische Studiën, 79, 339-351. Retrieved from https://lirias.kuleuven.be/1784519?limo=0 